Journal of Animal and Veterinary Advances $10(6): 757-763,2011$

ISSN: $1680-5593$

(C) Medwell Journals, 2011

\title{
mRNA Expression of Glutathione S-Transferase Pi (GSTP1) under Heat Stress and Association of Genotypes with Heat Tolerance Ability in Holstein
}

\author{
${ }^{1} \mathrm{Jia}$ Yao, ${ }^{1} \mathrm{Kun}$ Liao, ${ }^{2} \mathrm{Qiu}-$ Ling Li, ${ }^{2}$ Chang-Fa Wang, \\ ${ }^{2}$ Hong-Mei Wang, ${ }^{1}$ Song-Jia Lai and ${ }^{2} \mathrm{Ji}$-Feng Zhong \\ ${ }^{1}$ College of Animal Science and Technology, Sichuan Agricultural University, \\ Xinkang Road, 625014 Ya'an, Sichuan, China \\ ${ }^{2}$ Dairy Cattle Research Center, Shandong Academy of Agricultural Science, \\ 250100 Jinan, Shandong, China
}

\begin{abstract}
High ambient temperature has largely reduced the milk production due to the weak heat tolerance ability of Holstein. One potential mechanism for the destructive effect on organism is that the heat stress stimulated excessive cellular toxicants. The glutathione S-transferase Pi (GSTP1) has been proposed to play an important role to inactivate toxic metabolites in human malignant tumors. In this study, researchers evaluated the effect of heat stress on GSTP1 mRNA expression in Holstein using semi-quantitative RT-PCR method. With the liver tissue exception, the GSTP1 gene showed relatively high expression level in heart, spleen and kidney tissues in cool ambient temperature. After heat stress treatment, the GSTP1 mRNA expression increased significantly in all studied tissues. We sequenced the $3705 \mathrm{bp}$ fragment containing complete sequence of GSTP1 gene among 15 cows and detected 31 variations. The nonsynonymous variation of G18C (p.M6) was further scanned in 106 Holsteins using RFLP method to analyze the association of genotypes with heat tolerance ability. However, we did not detect statistical difference of heat tolerance ability among genotypes. To the knowledge, this is the first report to study GSTP1 mRNA expression under heat stress, SNPs distribution and association of genotypes with heat tolerance ability in Holstein. The significantly elevated expression of GSTP1 would suggest the positive role to resist heat stress, especially in liver tissue.
\end{abstract}

Key words: GSTP1, mRNA expression, SNPs, heat stress, Holstein, tissue

\section{INTRODUCTION}

The milk production of Holstein is very susceptible to high ambient temperature due to the weak heat tolerance ability which has strongly restricted the development of dairy industry in tropical regions and caused considerable economic loss (St-Pierre et al., 2003). The continuous genetic selection for higher production performances will inevitably result in greater susceptibility to heat stress. Although, many reports have been conducted to study the effect of heat stress on milk production, reproduction performance and immune system function in Holstein, the detailed molecular mechanisms has remained unknown (West, 2003; Argov et al., 2005; Aguilar et al., 2010). One alternative mechanism for the destructive effect on organism is that the heat stress directly and indirectly stimulates excessive intra/inter-cellular toxicants such as Malondialdehyde (MDA) and Reactive Oxygen Species (ROS) (Zuo et al., 2000; Yang and Lv, 2006). These intermediates can destroy cell membrane integrity by oxidating polyunsaturated fatty acids and further disturb biological metabolic function (Ikeda et al., 1999; Valko et al., 2004; Mene-Saffrane et al., 2009). Ravagnolo and Misztal estimated the genetic parameters in Holstein and found that the heat tolerance ability is partially genetically controlled (Ravagnolo and Misztal, 2000). However, the underlying functional gene(s) and the corresponding mechanism have largely remained unknown until now. The Glutathione S-Transferase Pi (GSTP1) belonging to glutathione S-transferase superfamily has been proposed to consistently express in a wide range of tissues in human including cornea, ciliary epithelium, prostate, placenta, breast, esophagus and lung (Ishioka et al., 1991; Hernando et al., 1992).

The best known physiological role of Glutathione S-Transferases (GSTs) is the detoxification by catalyzing the conjugation of many hydrophobic and electrophilic compounds with reduced glutathione (Perally et al., 2008; Chronopoulou and Labrou, 2009). Among them, the

Corresponding Author: Song-Jia Lai, Laboratory of Animal Genetic and Breeding, College of Animal Science and Technology, Sichuan Agriculture University, 46 Xingkang Road, 625014 Ya'an, Sichuan Province, China 
expression level and Single Nucleotide Polymorphisms (SNPs) of GSTP1 gene have been wildly reported to associate with the susceptibility to human tumors such as prostate cancer (Millar et al., 1999), acute lymphoblastic leukemia (Stanulla et al., 2000), endometrial cancer (Chan et al., 2005) and breast cancer (Oliveira et al., 2010). Under these biological processes, GSTP1 would play the central role in the detoxification of ROS and other toxic metabolites induced by carcinogenesis (Millar et al., 1999; Fryer et al., 2000; Yeh et al., 2010). In bovine, the GSTP1 shows $>85 \%$ homology of amino acid sequence with human (Hernando et al., 1992). So, researchers tentatively proposed that GSTP1 would play positive response under heat stress to alleviate the destructive effect on organism in Holstein by inactivating excessive metabolic toxicants which has not been reported to the knowledge.

During last decades, some physiological and biochemical indexes have been explored to evaluate the ability of heat tolerance. Among them, the Rectal Temperature (RT) and Potassium Content in Erythrocytes (PCE) were wildly adopted as heat tolerance indexes in Holstein. The lower RT and PCE values were always associated with better ability to resist heat stress (Olson et al., 2003; Su et al., 2006; Chen et al., 2007). In this study, we studied the effect of heat stress on mRNA expression of GSTP1 gene in Holstein. The SNPs distribution and their association of genotypes with heat tolerance ability evaluated by RT and PCE values were further analyzed. To systematically deduce this subject will be significant to improve the heat tolerance ability by genetic selection in Holstein.

\section{MATERIALS AND METHODS}

Animals: Total 112 healthy Holsteins at the 2nd or 3rd lactations were randomly collected in this study. They were treated with same feed nutrition supply and management schedule in experimental farm at Shandong Academy of Agricultural Science, Jinan, China. Among them, 6 cows with similar body weight and body condition score were further selected to study the effect of heat stress on GSTP1 gene mRNA expression while the remaining 106 individuals were further adopted to analyze the association of SNP in GSTP1 gene with heat tolerance ability.

Experimental design: The Temperature Humidity Index (THI) was employed to evaluate the heat stress degree (Bohmanova et al., 2007). This experiment began at early April, 2007 which was designed as cool ambient temperature (average THI was -60). Before test day, researchers measured dry bulb and wet bulb temperatures
3 times every day $(8: 00,14: 00$ and 20:00) and calculated the average THI for 3 days (Liu and Liang, 2006; Bohmanova et al., 2007). After this, the 6 cows were randomly divided into control group (continually kept in cool ambient temperature) and experimental group (treated with heavy heat stress). The 3 cows in experimental group were kept in artificial climate chamber for $24 \mathrm{~h}$ which was designed for $\mathrm{TH}$ of about 85 (corresponding to dry bulb temperature of $32 \pm 1^{\circ} \mathrm{C}$ and relative humidity of almost 75\%). Researchers evaluated GSTP1 gene mRNA expression between control group and experimental group by using the semi-quantitative RT-PCR method.

The individual heat tolerance ability was assessed based on the Rectal Temperature (RT) and Potassium Content in Erythrocytes (PCE). Researchers measured the RT value twice daily (8:00 and 14:00) and PCE value from jugular vein blood for the 106 cows at test day in the cool ambient temperature. The RT measurement was further repeated when the mean THI was up to 76.5 , almost in early August of the same year. The average RT values both in cool and hot ambient temperatures were finally adopted. The SNP distribution and frequencies of GSTP1 gene were determined by sequencing and Restriction Fragment Length Polymorphism (RFLP) methods.

PCE measurement: After $10 \mathrm{~mL}$ vein bloods were carefully collected at test day in the cool ambient temperature in the 106 cows, we isolated erythrocytes at a relative centrifugal force of $3,000 \mathrm{~g}$ for $20 \mathrm{~min}$. The erythrocytes were treated with deionized water and further digested overnight by mixed acid (the volume ratio of $\mathrm{HNO}_{3}$ and $\mathrm{HClO}_{4}$ was $5: 1$ ). After the pretreatment, the PCE was measured in AA6300 atomic absorption spectrophotometer (Shimadzu Co., Japan) and was presented as milligram per unit erythrocyte volume $\left(\mathrm{mg} \mathrm{L}^{-1}\right)$.

Total RNA extraction and cDNA synthesis: After the 6 cows from control group and experimental group were slaughtered by using electrical stunning, we immediately isolated the tissues of heart, liver, spleen and kidney. Total RNA was prepared for each tissue sample (100 mg) using $2 \mathrm{~mL}$ TRIzol reagent (Invitrogen Life Technologies, Shanghai, China) according to manufacturer's instructions. RNA integrity and concentration were subsequently tested. The total RNA treated with DNase was then converted to cDNA using the first-strand cDNA Reverse Transcription Kit (TaKaRa Bio Inc., Dalian, China).

Semi-quantitative RT-PCR: One primer pairs in exon 3 for GSTP1 gene amplification were designed according to 
Table 1: The primers used to RT-PCR analysis and to amplify GSTP1 gene

\begin{tabular}{lllrr}
\hline Purposes & $\begin{array}{c}\text { Genes/ } \\
\text { fragments }\end{array}$ & Primers $\left(5^{\prime} \rightarrow 3^{\prime}\right)$ & $\begin{array}{c}\text { Annealing } \\
\text { Locations }\end{array}$ & $\begin{array}{c}\text { Amperatures }\left({ }^{\circ} \mathrm{C}\right) \\
\text { tem }\end{array}$ \\
\hline RT-PCR & GSTP1 & AACTACGAGGCGGGCAAGG; CTGGTCGCCCACGATGAA & $404-517$ & 60.5 \\
& $\beta$-actin & CATCCGCAAGGACCTCTAC; ATGCCAATCTCATCTCGTTTT & $956-1295$ & 60.5 \\
To amplify & Primer 1 & CTCCAAACGGTCCACG; GGGTAGCCTATCCCTTCG & $-408-1146$ & 63.5 \\
GSTP1 gene & Primer 2 & AATGGAGGCGTGTGGAGGT; CCACCCAGAACCAGAAGCAGC & $1017-1667$ & 60.5 \\
& Primer 3 & ACGGTGTAGAGGACCTTCGCT; TGTTTCCCATTGCCGTTGAT & $1486-2784$ & 62.5 \\
& Primer 4 & ACCTGCTGGACCTGCTTCG; AGGCAGATTCTTTCCTGTTTGAG & $2619-3285$ & 62.0 \\
& Primer 5 & GCCAGGAGGATGATACCCAG; TGTTTCCATTGCCGTTGAT & $2290-2784$ & 61.0 \\
& Primer 6 & CCTGCTGGACCTGCTTCGGA; CTCCCACATATGAGGCAGA & $2620-3297$ & 63.0 \\
\hline
\end{tabular}

mRNA sequence of cattle (GenBank acc. no. NM_177516). Another primer pairs were also used to amplify $\beta$-actin gene (Table 1 ). The 2 primer pairs were approved to be noncompetitive. Preliminary experiments were conducted to determine the appropriate number of PCR cycles to assure that the amplification was in the exponential range and could be linearly quantified; the 24-30 PCR cycles were tested. Semi-quantitative RT-PCR was conducted in the same tube to compare the relative expression ratio of GSTP1 gene to $\beta$-actin gene. PCR amplifications were carried out in $50 \mu \mathrm{L}$ reaction mixture containing $0.5 \mu \mathrm{L}$ of each primer $(10 \mathrm{pM}), 10 \mu \mathrm{L}$ cDNA, 2.5 unit LA Taq DNA Polymerase and $25 \mu \mathrm{L} 2 \times \mathrm{GC}$ buffer I (TaKaRa Bio Inc., Dalian, China) followed by $4 \mathrm{~min}$ at $94^{\circ} \mathrm{C}, 26$ cycles of $30 \mathrm{sec}$ at $94^{\circ} \mathrm{C}, 30 \mathrm{sec}$ at $60.5^{\circ} \mathrm{C}, 30 \mathrm{sec}$ at $72^{\circ} \mathrm{C}$, an additional $5 \mathrm{~min}$ extension step. The RT-PCR products were stained by GoldView on $1.2 \%$ agarose gel. The signal intensity of each PCR product was scored by using quality one 4.6.2 software to calculate the ratio of GSTP1 to $\beta$-actin mRNA expression. This protocol was performed in the 6 cows from both control group and experimental group.

GSTP1 gene sequencing and SNPs identification: Genomic DNA was extracted by using standard phenol/chloroform method. Total 6 primers were developed according to cattle genome sequence (GenBank acc. no. NW_001494541) to amplify the 5'flanking region, exon/intron complete sequences and 3'-flanking region sequences among 15 randomly selected individuals (Table 1). PCR amplifications were performed in a $50 \mu \mathrm{L}$ reaction mixture containing $100 \mathrm{ng}$ of DNA, $10 \mathrm{mM}$ Tris- $\mathrm{HCl}$ (pH 8.3), $2.5 \mathrm{mM} \mathrm{MgCl}_{2}, 50 \mathrm{mM} \mathrm{KCl}$, $10 \mathrm{pM}$ of each primer and 2.5 unit LA Taq DNA Polymerase under the procedures of 35 cycles at $94^{\circ} \mathrm{C}$ for $45 \mathrm{sec}$ at individual annealing temperature (Table 1) for $60 \mathrm{sec}$ and at $72^{\circ} \mathrm{C}$ for $1 \mathrm{~min}$. All PCR products were purified on spin columns and were directly sequenced for both strands with amplification primers using a Big Dye Terminator v. 3.1 Cycle Sequencing Kit (Applied Biosystems) on an ABI Prism 3100 DNA sequencer according to manufacturer's manual. After sequences were artificially checked, the variable sites were determined in Mutation Surveyor 2.28 software.
PCR-RFLP: In order to investigate, the allele frequencies, one nonsynonymous SNP (G18C in exon 1) was successfully developed for RFLP analysis using restriction endonuclease BstXI. The PCR reactions were performed in a volume of $25 \mu \mathrm{L}$ reaction mixture containing $50 \mathrm{ng}$ of DNA, $10 \mathrm{mM}$ Tris- $\mathrm{HCl}(\mathrm{pH} 8.3)$, $2.5 \mathrm{mM} \mathrm{MgCl}_{2}, 50 \mathrm{mM} \mathrm{KCl}, 10 \mathrm{pM}$ of each primer and 1 unit of Taq polymerase $\left(\mathrm{S}_{\mathrm{ABC}}\right)$ which were carried out under the PCR program with $5 \mathrm{~min}$ denaturation at $94^{\circ} \mathrm{C}$, 30 cycles for $1 \mathrm{~min}$ denaturation at $94^{\circ} \mathrm{C}, 1 \mathrm{~min}$ annealing at $63.5^{\circ} \mathrm{C}, 1 \mathrm{~min}$ extension at $72^{\circ} \mathrm{C}$ and a final extension for $7 \mathrm{~min}$ at $72^{\circ} \mathrm{C}$. The PCR product was digested with restriction endonucleases BstXI and detected in a $1.5 \%$ agarose gel electrophoresis.

Statistical analysis: The effect of heat stress treatment on GSTP1 gene mRNA expression in different tissues was statistically analyzed using t test. Least square means of RT and PCE values were estimated under general linear model with GSTP1 genotypes as fixed factor using SAS statistical software package (SAS Institute Inc., Cary, NC, USA). Considering the fact that all cows adopted in this study were from one breed, one farm, same seasons and similar ages (lactations), researchers only evaluated the effect of GSTP1 genotypes on heat tolerance ability.

\section{RESULTS AND DISCUSSION}

Effect of heat stress on GSTP1 mRNA expression: In cool ambient temperature (the average THI was - 60), the GSTP1 gene showed relatively high expression level in heart, spleen and kidney tissues whereas we hardly detected mRNA expression in liver tissue (Fig. 1). After the simulated heat stress treatment, the GSTP1 mRNA expression significantly increased in all studied tissues ( $\mathrm{p}<0.05$ or $\mathrm{p}<0.01$ ). Among the 4 tissues, heart tissue showed the highest expression level both in cool ambient temperature and after heat stress treatment.

SNPs identification in GSTP1 gene: Researchers successfully obtained the $3705 \mathrm{bp}$ fragment of GSTP1 gene consisting of $408 \mathrm{bp}$ of 5 -flanking region, the completesequence of 7 exons and 6 introns and 428 bp of 


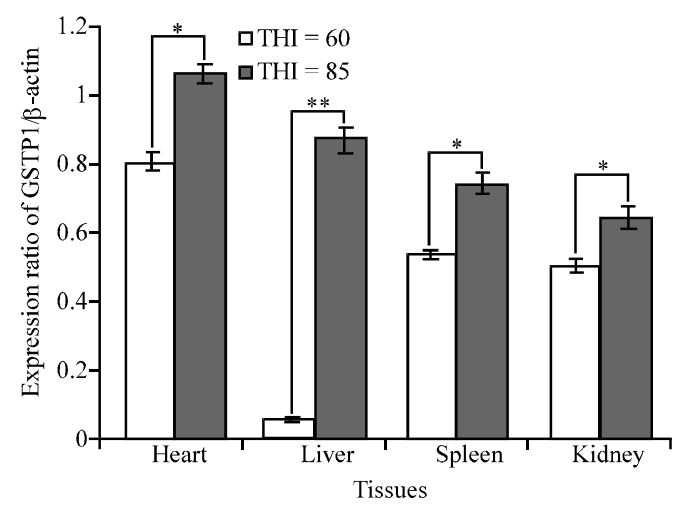

Fig. 1: Changes of mRNA expression ratio of GSTP1 gene to $\beta$-actin gene under heat stress treatment in different tissues of Holsteins. Bars were calculated based on the density and width of electrophoresis bands using quality one 4.6.2 software. White and black showed the control group and experimental group. The significant difference were further marked by ${ }^{*}$ and ${ }^{* *}$ on 0.05 and 0.01 levels, respectively

3'-flanking region. Total 31 variations were detected among the 15 sequenced individuals, consisting of three deletions, one insert, 24 transitions and 3 transversions (Table 2). Among them, 14 variations (45.2\%) had already been reported in Hereford cattle. These variations were distributed in the region of -346 th 3171 st sites and showed relatively high mutation frequencies in 3rd-6th intron regionsand 7 th extron. Total 2 fragment deletion events were detected at -346 th and 3086th sites, respectively (Table 2 ).

PCR-RFLP and association analysis: The nonsynonymous variation of G18C (p.M6) occurred in exon 1 was successfully subjected to PCR-RFLP analysis by using restriction endonucleases BstXI. The PCR product was digested into 1123 and $431 \mathrm{bp}$ fragments due to the transversion of $\mathrm{G} 18 \mathrm{C}$.

The frequencies of $\mathrm{CC}, \mathrm{CG}$ and $\mathrm{GG}$ genotypes among 106 cows were $24.5 \%$ (26), 49.1\% (52) and 26.4\% (28), respectively (Table 3 ). The frequencies of $\mathrm{C}$ and $\mathrm{G}$ alleles were 49.1 and $50.9 \%$. The effects of different genotypes on heat tolerance ability were evaluated (Table 3 ). There was no significant effect of genotypes on heat tolerance ability evaluated by both the PCE value $(p=0.6620)$ and the $R T$ value $(\mathrm{p}=0.5067)$. The highest and the lowest least square means were $677.44 \pm 57.01 \mathrm{mg} \mathrm{L}^{-1}$ (CG genotype) and $601.20 \pm 77.69 \mathrm{mg} \mathrm{L}^{-1}$ (GG genotype) for PCE value. Meanwhile, GG genotype had highest RT value $\left(39.46 \pm 0.09^{\circ} \mathrm{C}\right)$ and CC genotype had the lowest RT value $\left(39.32 \pm 0.10^{\circ} \mathrm{C}\right)$ Glutathione S-transferase superfamilies, consisting of 5 classes of alpha, pi, mu,
Table 2: Sequence variations of GSTP1 gene in Holsteins

\begin{tabular}{|c|c|c|c|}
\hline IDs & Locations & Types & $\begin{array}{c}\text { GenBank } \\
\text { accession nos }\end{array}$ \\
\hline 1 & $-346-337$ (5' end) & Del GGTGCACAGG & \\
\hline 2 & $-209\left(5^{\prime}\right.$ end $)$ & $\mathrm{T}>\mathrm{C}$ & \\
\hline 3 & $-81\left(5^{\prime}\right.$ end $)$ & $\mathrm{A}>\mathrm{G}$ & \\
\hline 4 & 18 (Exon 1$)$ & $\mathrm{G}>\mathrm{C}$ & \\
\hline 5 & $29($ Exon 1$)$ & $\mathrm{G}>\mathrm{A}$ & \\
\hline 6 & 210 (Intron 1$)$ & $\mathrm{A}>\mathrm{G}$ & \\
\hline 7 & 326 (Intron 2) & $\mathrm{C}>\mathrm{T}$ & rs42188155 \\
\hline 8 & 386 (Intron 2) & $\mathrm{C}>\mathrm{T}$ & rs 42188154 \\
\hline 9 & 699 (Intron 3) & $\mathrm{T}>\mathrm{C}$ & \\
\hline 10 & 708 (Intron 3) & Del C & \\
\hline 11 & 746 (Intron 3) & $\mathrm{A}>\mathrm{G}$ & $\mathrm{rs} 42188153$ \\
\hline 12 & 915 (Intron 4) & $\mathrm{A}>\mathrm{G}$ & rs 42188152 \\
\hline 13 & 940 (Intron 4) & $\mathrm{C}>\mathrm{T}$ & rs42188151 \\
\hline 14 & 1229 (Intron 4) & $\mathrm{A}>\mathrm{G}$ & rs17871923 \\
\hline 15 & $1760($ Intron 5) & $\mathrm{A}>\mathrm{G}$ & $\mathrm{rs} 42188150$ \\
\hline 16 & 1793 (Intron 5) & $\mathrm{T}>\mathrm{C}$ & rs 42188149 \\
\hline 17 & 1905 (Intron 5) & $\mathrm{G}>\mathrm{A}$ & $\mathrm{rs} 42188147$ \\
\hline 18 & 2332 (Exon 6 ) & $\mathrm{A}>\mathrm{G}$ & \\
\hline 19 & 2453 (Intron 6) & $\mathrm{G}>\mathrm{A}$ & \\
\hline 20 & 2508 (Intron 6) & $\mathrm{G}>\mathrm{A}$ & \\
\hline 21 & 2567 (Intron 6) & $\mathrm{G}>\mathrm{A}$ & rs42188146 \\
\hline 22 & $2746($ Exon 7$)$ & $\mathrm{G}>\mathrm{C}$ & rs 42188145 \\
\hline 23 & $2796($ Exon 7$)$ & $\mathrm{T}>\mathrm{C}$ & rs42188144 \\
\hline 24 & $2797($ Exon 7$)$ & $\mathrm{G}>\mathrm{A}$ & rs 42188143 \\
\hline 25 & $2809($ Exon 7) & $\mathrm{G}>\mathrm{T}$ & rs 42188142 \\
\hline 26 & $2829($ Exon 7$)$ & $\mathrm{T}>\mathrm{C}$ & \\
\hline 27 & 2833-2834 (Exon 7) & Ins $\mathrm{C}$ & \\
\hline 28 & 3078-(3' end) & $\mathrm{A}>\mathrm{G}$ & \\
\hline 29 & 3086-3092 ( $3^{\prime}$ end) & Del AAAGTGA & \\
\hline 30 & 3166 ( $3^{\prime}$ end $)$ & $\mathrm{T}>\mathrm{C}$ & \\
\hline 31 & 3171 ( $3^{\prime}$ end $)$ & $\mathrm{G}>\mathrm{A}$ & \\
\hline
\end{tabular}

Table 3: Least square means of genotypes for PCE and RT values Traits $^{b}$

Sites Genotypes $\mathrm{N}(\%)^{\mathrm{a}} \quad \mathrm{PCE}\left(\mathrm{mg} \mathrm{L}^{-1}\right) \quad \mathrm{RT}\left({ }^{\circ} \mathrm{C}\right) \quad \mathrm{p}$-values

$\begin{array}{lllllll}\mathrm{G} 18 \mathrm{C} & \mathrm{CC} & 26(24.5) & 609.05 \pm 80.62 & 39.32 \pm 0.10 & 0.6620(\mathrm{PCE})\end{array}$ $\begin{array}{llllll}\mathrm{CG} & 52(49.1) & 677.44 \pm 57.01 & 39.35 \pm 0.07 & 0.5067 & \text { (RT) }\end{array}$ GG $\quad 28(26.4) \quad 601.20 \pm 77.69 \quad 39.46 \pm 0.09 \quad$ -

Total - $\quad 106$

a) The genotypes which occurred in less than 10 individuals were excluded to calculate least square mean values; ${ }^{\text {b) }}$ All least square means for PCE (Potassium content in erythrocytes) and RT (Rectal temperatures) values had no statistical differences among different genotypes

theta and zeta in human have been identified to be involved in conjugation of electrophilic compounds to reduced glutathione (Mannervik et al., 1992; Ntais et al., 2005; Chronopoulou and Labrou, 2009). Among them, GSTP1 gene (pi-class) polymorphism and expression analyses were wildly reported in various malignant diseases.

Wang et al. (2004) studied the expression of GSTP1 gene in various prostatic disease types and suggested that GSTP1 may be associated with the genesis and progress of prostate carcinoma. Chan et al. (2005) found that the Ile105Val polymorphism of GSTP1 gene was associated with an increased risk of endometrial cancer. The association of genotypes were also reported in 
prostate cancer (Millar et al., 1999), acute lymphoblastic leukemia (Stanulla et al., 2000) and breast cancer (Chan et al., 2005). The positive biological role of GSTP1 in these genesis processes is to detoxify ROS and other toxic metabolites induced by malignant pathological changes (Eaton and Bammler, 1999; Fryer et al., 2000; Chung et al., 2009). The Temperature Humidity Index (THI) was wildly adopted to evaluate the heat stress degree in Holstein (Bohmanova et al., 2007; Avendano-Reyes et al., 2010). When THI index exceeds 76 cow will be suffering from heavy heat stress and exhibited significantly decreased milk production (West, 2003). The destructive effect of heat stress on organism might take place via stimulating excessive cellular toxicants such as ROS and MDA (Zuo et al., 2000; Yang and Lv, 2006). So, researchers tentatively inferred that GSTP1 would play the protective role under heat stress by inactivating the excessive metabolic toxicants. In this study, we kept Holsteins in artificial climate chamber for $24 \mathrm{~h}$ which was designed the heavy heat stress condition and found that heat stress treatment significantly elevated the mRNA level of GSTP1 gene in all studied tissues. Most interesting, the mRNA expression of GSTP1 in liver tissue was hardly detected in cool ambient temperature which was strikingly contrasted to that after heat stress treatment (Fig. 1).

One early report also suggested that GSTP1 gene hardly expressed in normal liver tissue of rat while high expression appeared in pathological cells of liver cancer (Sato, 1989). In addition, high expression of GSTP1 gene has been wildly reported in many malignant human tumors (Wang et al., 1997; Kolwijck et al., 2009). These results would suggest that the elevated expression of GSTP1 gene especially in liver tissue might play the positive response to resist the destructive effect of heat stress in Holstein.

The RT was wildly acceptable to evaluate the ability for maintaining homeostasis in deep body temperature and the low RT value was associated with high resistance ability to heat stress (Olson et al., 2003). In addition, the PCE was proved to be a reliable and practical heat-tolerant index in Holstein and the high heat tolerance ability was proposed to be less than the threshold of $800 \mathrm{mg} \mathrm{L}^{-1}$ (Liu et al., 1997; Su et al., 2006; Chen et al., 2007). In this study, we combined the two indexes together to study the association of genotypes with heat tolerance ability in Holsteins on the SNP of G18C variation which occurred in exon 1 and resulted in amino acid mutation.

The lowest least square means of PCE and RT were presented in GG and $\mathrm{CC}$ genotypes, respectively. However, researchers did not detect statistical difference of heat tolerance ability among genotypes. In contrast, the significant associations of polymorphism in GSTP1 gene with susceptibility to various tumors have been reported in human (Millar et al., 1999; Stanulla et al., 2000; Chan et al., 2005; Singh et al., 2008). More SNPs in GSTP1 gene should be further investigated to deduce the association of genotypes with heat tolerance ability in Holstein.

\section{CONCLUSION}

To the knowledge, this is the first report to study GSTP1 mRNA expression under heat stress, SNPs distribution and association of genotypes with heat tolerance ability in Holstein. Although, researchers failed to detect the significant association of genotypes of GSTP1 with heat tolerance ability, the significantly elevated expression in all studied tissues under heat stress treatment especially in liver tissue also confirm the positive role of GSTP1 to resist the heat stress in Holstein.

\section{ACKNOWLEDGEMENT}

This research was financially supported by High Technology Independent Innovation Project from Shandong Academy of Agriculture Science (2006YCX028).

\section{REFERENCES}

Aguilar, I., I. Misztal and S. Tsuruta, 2010. Short communication: Genetic trends of milk yield under heat stress for US Holsteins. J. Dairy Sci., 93: 1754-1758.

Argov, N., U. Moallem and D. Sklan, 2005. Summer heat stress alters the mRNA expression of selectiveuptake and endocytotic receptors in bovine ovarian cells. Theriogenology, 64: 1475-1489.

Avendano-Reyes, L., J.W. Fuquay, R.B. Moore, Z. Liu, B.L. Clark and C. Vierhout, 2010. Relationship between accumulated heat stress during the dry period, body condition score, and reproduction parameters of Holstein cows in tropical conditions. Trop. Anim. Health Prod., 42: 265-273.

Bohmanova, J., I. Misztal and J.B. Cole, 2007. Temperature-humidity indices as indicators of milk production losses due to heat stress. J. Dairy Sci., 90: 1947-1956.

Chan, Q.K., U.S. Khoo, H.Y. Ngan, C.Q. Yang and W.C. Xue et al., 2005. Single nucleotide polymorphism of pi-class glutathione s-transferase and susceptibility to endometrial carcinoma. Clin. Cancer Res., 11: 2981-2985. 
Chen, Q., Z.H. Li and G.L. Wang, 2007. Polymorphisms of HSP70 gene and as sociation with production performance in holstein. Acta Agric. Jiangxi, 19: 84-86.

Chronopoulou, E.G. and N.E. Labrou, 2009. Glutathione transferases: Emerging multidisciplinary tools in red and green biotechnology. Recent Pat. Biotechnol., 3: $211-223$.

Chung, J., S.Y. Oh and Y.K. Shin, 2009. Association of glutathione-s-transferase polymorphisms with atopic dermatitis risk in preschool age children. Clin. Chem. Lab. Med., 47: 1475-1481.

Eaton, D.L. and T.K. Bammler, 1999. Concise review of the glutathione s-transferases and their significance to toxicology. Toxicol. Sci., 49: 156-164.

Fryer, A.A., A. Bianco and M. Hepple, 2000. Polymorphism at the glutathione S-transferase GSTP1 locus. A new marker for bronchial hyperresponsiveness and asthma. Am. J. Respir. Crit. Care Med., 161: 1437-1442.

Hernando, N., J.M. Martin-Alonso, S. Ghosh and M. Coca-Prados, 1992. Isolation of a cdna encoding a glutathione s-transferase (GST) class-pi from the bovine ocular ciliary epithelium. Exp. Eye Res., 55: $711-718$.

Ikeda, M., H. Kodama, J. Fukuda, Y. Shimizu, M. Murata, J. Kumagai and T. Tanaka, 1999. Role of radical oxygen species in rat testicular germ cell apoptosis induced by heat stress. Biol. Reprod, 61: 393-399.

Ishioka, C., R. Kanamaru, H. Shibata, Y. Konishi and A. Ishikawa et al., 1991. Expression of glutathione stransferase-pi messenger rna in human esophageal cancers. Cancer, 67: 2560-2564.

Kolwijck, E., P.L. Zusterzeel, H.M. Roelofs, J.C. Hendriks, W.H. Peters and L.F. Massuger, 2009. GSTP1-1 in ovarian cyst fluid and disease outcome of patients with ovarian cancer. Cancer Epidemiol. Biomarkers Prev., 18: 2176-2181.

Liu, Q.H. and X.W. Liang, 2006. SSCP polymorphism of the HSPA1A gene and its relationship with heat tolerant capacity of Jersey and Holstein cows. Fujian J. Agric. Sci., 21: 321-324.

Liu, Y.Q., D. Xia and R.Z. Li, 1997. Studies on distribution of potassium content in erythrocytes of holstein. J. Nanjing Agric. Univ., 20: 55-59.

Mannervik, B., Y.C. Awasthi, P.G. Board, J.D. Hayes and C. Di Ilio et al., 1992. Nomenclature for human glutathione transferases. Biochem. J., 282: 305-306.

Mene-Saffrane, L., L. Dubugnon, A. Chetelat, S. Stolz, C. Gouhier-Darimont and E.E. Farmer, 2009. Nonenzymatic oxidation of trienoic fatty acids contributes to reactive oxygen species management in arabidopsis. J. Biol. Chem., 284: 1702-1708.
Millar, D.S., K.K. Ow, C.L. Paul, P.J. Russell, P.L. Molloy and S.J. Clark, 1999. Detailed methylation analysis of the glutathione s-transferase pi (GSTP1) gene in prostate cancer. Oncogene, 18: 1313-1324.

Ntais, C., A. Polycarpou and J.P. Ioannidis, 2005. Association of GSTM1, GSTT1 and GSTP1 gene polymorphisms with the risk of prostate cancer: A meta-analysis. Cancer Epidemiol Biomarkers Prev., 14: 176-181.

Oliveira, A.L., F.F. Rodrigues, R.E. Santos, T. Aoki, M.N. Rocha, C.A. Longui and M.B. Melo, 2010. GSTT1, GSTM1 and GSTP1 polymorphisms and chemotherapy response in locally advanced breast cancer. Genet. Mol. Res., 9: 1045-1053.

Olson, T.A., C. Lucena, C.C. Jr. Chase and A.C. Hammond, 2003. Evidence of a major gene influencing hair length and heat tolerance in bos taurus cattle. J. Anim. Sci., 81: 80-90.

Perally, S., E.J. Lacourse, A.M. Campbell and P.M. Brophy, 2008. Heme transport and detoxification in nematodes: Subproteomics evidence of differential role of glutathione transferases. J. Proteome. Res., 7: 4557-4565

Ravagnolo, O. and I. Misztal, 2000. Genetic component of heat stress in dairy cattle, parameter estimation. J. Dairy Sci., 83: 2126-2130.

Sato, K., 1989. Glutathione transferases as markers of preneoplasia and neoplasia. Adv. Cancer Res., 52: 205-205.

Singh, M., P.P. Shah, A.P. Singh, M. Ruwali, N. Mathur, M.C. Pant and D. Parmar, 2008. Association of genetic polymorphisms in glutathione S-transferases and susceptibility to head and neck cancer. Mutat. Res., 638: 184-194.

St-Pierre, N.R., B. Cobanov and G. Schnitkey, 2003. Economic losses from heat stress by US livestock industries. J. Dairy Sci., 86: E52-E77.

Stanulla, M., M. Schrappe, A.M. Brechlin, M. Zimmermann and K. Welte, 2000. Polymorphisms within glutathione s-transferase genes (GSTM1, GSTT1, GSTP1) and risk of relapse in childhood b-cell precursor acute lymphoblastic leukemia: A case-control study. Blood, 95: 1222-1228.

Su, G.H., B.N. Xiao and H.F. Yan, 2006. Study on the genetic marker of potassium content in erythrocytes for heat tolerance in holstein cows. China Dairy Cattle, 9: 35-37.

Valko, M., M. Izakovic, M. Mazur, C.J. Rhodes and J. Telser, 2004. Role of oxygen radicals in DNA damage and cancer incidence. Mol. Cell. Biochem., 266: $37-56$. 
Wang, H.B., M.F. Ye and Y.L. Wang, 2004. Expression of GSTP1 in tissues of differentprostatic diseases and its significance. J. Regional Anat. Operative Surg, 13: 73-75.

Wang, X., Z.P. Pavelic, Y. Li, L. Gleich and P.S. Gartside et al., 1997. Overexpression and amplification of glutathione S-transferase pi gene in head and neck squamous cell carcinomas. Clin. Cancer Res., 3: 111-114.

West, J.W., 2003. Effects of heat-stress on production in dairy cattle. J. Dairy Sci., 86: 2131-2144.
Yang, D.B. and P. Lv, 2006. The effect of heat stress on anti-oxidation ability in Holstein cow. Prog. Veter. Med., 27: 99-100.

Yeh, C.C., C.Y. Lai, L.L. Hsieh, R. Tang, F.Y. Wu and F.C. Sung, 2010. Protein carbonyl levels, glutathione S-transferase polymorphisms and risk of colorectal cancer. Carcinogenesis, 31: 228-233.

Zuo, L., F.L. Christofi, V.P. Wright, C.Y. Liu, A.J. Merola, L.J. Berliner and T.L. Clanton, 2000. Intra- and extracellular measurement of reactive oxygen species produced during heat stress in diaphragm muscle. Am. J. Physiol. Cell Physiol., 279: C1058-C1066. 